\title{
Mendidik dan Mendiagnosa Anak Usia Dini yang Mempunyai Gangguan Autis dengan Mengetahui Problem-Problemnya
}

\author{
Hayyan Ahmad Ulul Albab \\ Program Studi PIAUD, Fakultas Agama Islam, Universitas Islam Lamongan \\ Jl.Veteran No. 53 A Lamongan 62213 \\ E-mail: hayyan.ahmad27@gmail.com
}

\begin{abstract}
Autism is a lifelong disability that affects a person in social communication, social interaction, dealing with his environment and the imagination of a child who bears autism is like aliving in his own world. Lack of a child's ability to engage in understanding that includes, understands language, plays, and communicates with others. A diagnosis that a child has autism is by referring to ICD-10 (International Clasification of Disease) or using formulation in DSM-IV (Diagnostic Statistical Manual). The types of therapy that can be given to children with autism are behavioral therapy, occupational therapy, speech therapy, socialization with the aim to eliminate unnatural behavior, biomedical therapy (drugs, vitamins, minerals, food supplements), socialization to regular schools and School of Children with Special Needs. The problem of autistic students that will be faced during school age is Communication Abilities, Social Skills, Behavior Problems, Adaptive Living Skills problem in understanding the world and dificult behavior and emotional problems
\end{abstract}

Keyword: Autism, Diagnose, Problems

\begin{abstract}
Autis adalah cacat seumur hidup yang mempengaruhi seseorang dalam berkomunikasi sosial, interaksi sosial, berhubungan dengan lingkungannya dan imajinasi anak yang menyandang autis seakan-akan hidup di dunianya sendiri. Kurangnya kemampuan seorang anak untuk melakukan pemahaman yang meliputi, memahami bahasa, bermain, dan berkomunikasi dengan orang lain. Sebuah diagnosa bahwa seorang anak mengidap autis adalah dengan merujuk pada ICD-10 (International Clasification of Disease) atau menggunakan rumusan dalam DSM-IV (Diagnostic Statistical Manual). Jenisjenis terapi yang bisa diberikan pada anak autis yaitu Terapi perilaku, Terapi okupasi, Terapi wicara, Sosialisasi dengan tujuan untuk menghilangkan perilaku yang tidak wajar, Terapi biomedik (obat, vitamin, mineral, food suplement), Sosialisasi ke sekolah reguler dan Belajar di Sekolah Anak Berkebutuhan Khusus. Problem siswa autis yang akan dihadapi pada saat usia sekolah yaitu Communication Abilities, Social Skills, Behavior Problems, Adaptive Living Skills problem in understanding the world and dificult behaviour and emotional problems
\end{abstract}

Keyword: Autis, Diagnose, Problems

\section{A. Tinjauan Tentang Autis}

Jumlah penyandang autisme dari waktu ke waktu tampaknya semakin meningkat pesat. Autis seolah-olah mewabah keberbagai belahan dunia. Di beberapa negara terdapat 
kenaikan angka kejadian penyandang autisme yang cukup tajam. Jumlah tersebut di atas angat menghawatirkan mengingat sampai saat ini penyebab autisme masih misterius dan masih menjadi perdebatan diantara pakar kesehatan didunia.

\section{Pengertian Autis}

Kate Wall mendefinisikan tentang definisi autis sebagai berikut: Autis adalah cacat seumur hidup yang mempengaruhi seseorang dalam berkomunikasi dan berhubungan dengan lingkungannya. Anak-anak dengan autisme mengalami kesulitan dalam berhubungan dengan orang lain. Kemampuan mereka untuk mengembangkan persahabatan umumnya terbatas karena kapasitas mereka untuk memahami ekspresi emosi orang lain. Hal tersebut berlaku pada beberapa anak saja dan semua anak dengan autisme memiliki gangguan dalam interaksi sosial, komunikasi sosial dan imajinasi. Hal ini dikenal sebagai tiga serangkai gangguan. ${ }^{1}$

Dari pendapat Y. Handojo, pengertian autisme berasal dari kata "Auto" yang berarti sendiri, yaitu anak yang menyandang autisme seakan-akan hidup di dunianya sendiri. $^{2}$

Adapun menurut David Smith, autism adalah suatu kelainan ketidakmampuan interaksi komunikasi dan sosial. ${ }^{3}$

Menurut Badrut Tamam, anak autisme adalah anak yang dalam proses pertumbuhan dan perkembangannya secara signifikan (bermakna) mengalami kelainan atau penyimpangan, kelainan itu bisa terjadi pada fisik, mental-intelektual, sosial, maupun emosional. ${ }^{4}$

Autis adalah cacat mental yang mempengaruhi kemampuan seorang anak untuk melakukan pemahaman yang meliputi, memahami bahasa, bermain, dan berkomunikasi dengan orang lain atau Anak autis adalah anak yang memiliki cacat dibeberapa fungsi otak yang bisa mempengaruhi fungsi komunikasi sosial. Sebuah sindrom perilaku autis ini didasarkan pada bentuk perilaku yang dikeluarkan oleh seorang individu. Hal ini telah dikonfirmasikan bahwa autis bukanlah penyakit melainkan sindrom yang tidak menular hanya dengan melalui interaksi dengan lingkungannya dan keberadaannya di bawah sejak sejak lahir, sindrom ini muncul sebelum usia tiga dan bisa mempengaruhi fungsi otak . ${ }^{5}$

Dapat dipahami bahwa pengertian autis adalah sebutan kepada anak atau seseorang atau nama dari kelainan kebiasaan atau tingkah laku dengan ciri-ciri penyimpangan interaksi sosial, bahasa yang diucapkannya, kontak mata, bahasa tubuh dan pendekatan sosial, terutama kurangnya hubungan sosial dengan orang lain.

\section{Faktor-faktor yang Menyebabkan Autis}

Faktor yang menyebabkan autis sendiri masih belum jelas benar dan bagaimana terjadinya gejala dari autisme ini, akan tetapi banyak pakar dalam bidang

\footnotetext{
${ }^{1}$ Kate Wall, Autism and Early Years Practice (London: Sage Publications LTD, 2010), 7.

${ }^{2}$ Y. Handojo, Autisma Petunjuk Praktis dan Pedoman Materi Untuk Mengajar Anak Normal Autis dan Perilaku Lain (Jakarta: Buana Ilmu Populer, 2003), 12.

${ }^{3}$ J. David Smith, Inklusi Sekolah Ramah Untuk Semua (Bandung: Nuansa, 2006), 150.

${ }^{4}$ Badrut Tamam, Pelita Jukbil Untuk Anak Autis (Jawa Pos: 28 Pebruari, 2008), 37.

${ }^{5}$ Sa'ad Riya $>$ d $\}$, Al- T\{ifl al-Tawh\}idy: Asra>r al-T\{ifl al-Dha>tawy> wa kayfa Nataa<'mal Maa'hu (Mesir: Da>r al-Qahirah lilja>mia>'t, 2008), 14.
} 
ini telah sepakat bahwa faktor-faktor yang menyebabkan anak autisme adalah pada otak anak autisme dijumpai suatu kelainan. Ada tiga lokasi di otak yang ternyata mengalami kelainan neuro-anatomis atau fungsi otak.

Berikut beberapa penyebab autis, diantaranya: Pertama, faktor genetik, kurang lebih dua puluh persen kasus autis itu disebabkan oleh faktor genetik. Penyakit genetik ini sering dihubungkan dengan autis atau biasa disebut dengan sindrom fragile- $\mathrm{X}$ karena penyakit ini ditandai dengan kerapuhan yang terjadi pada ujung lengan kromosom x. ${ }^{6}$ Kedua, gangguan pada sistem saraf, banyak penelitian yang melaporkan tentang anak autis yang memiliki kelainan pada struktur otaknya dan kelainan yang paling sering terjadi yaitu pada otak kecil. Laporan yang diberikan oleh peneliti menyebutkan bahwa berkurangnya sel purkinye di otak kecil pada anak autis dapat merangsang pertumbuhan akson, glia dan myelin sehingga terjadi pertumbuhan otak yang abnormal. ${ }^{7}$

Sedangkan menurut Y. Handojo, Faktor-faktor yang menyebabkan autis antara lain adalah:

a. Genetika (faktor keturunan) ditengarai adanya kelainan kromosom pada anak autisme, namun kelainan ini tidak berada pada kromosom yang selalu sama.

b. Infeksi virus dan jamur yang terdiri dari toksoplasmosis, rubella, candida yang menyebabkan tingkah laku yang tidak pantas dan masalah kesehatan pada anak autismem

c. Kekurangan nutrisi dan oksigenasi.

d. Polusi udara, air dan makanan.

e. Sensory interpretation errors yaitu rangsangan yang berasal dari reseptor visual, auditori, dan taktil yang mengalami proses yang kacau pada otak anak sehingga timbul persepsi yang semrawut, kacau atau berlebihan yang pada akhirnya menyebabkan kebingungan dan ketakutan pada anak. Akibatnya anak menarik diri dari lingkungan yang "menakutkan" tersebut. ${ }^{8}$

Dari faktor-faktor penyebab anak autisme yang telah dijelaskan di atas, maka anak autisme dapat sembuh atau menjadi normal kembali dengan cara membutuhkan penggunaan terapi-terapi khusus atau metode-metode khusus dalam belajar mengajar. Akan tetapi hal ini akan membutuhkan waktu yang relatif tidak singkat dan penanganannya tidak sesederhana yang diperkirakan.

Banyak para profesi yang perlu dilibatkan, seperti ahli laboratorium tertentu, ahli keracunan logam berat, ahli gizi tertentu dan sebagainya. Yang paling disorot dari faktor yang menyebabkan autis adalah paparan logam berat terutama merkuri dan timbal dari lingkungan. Oleh karena itu, apabila di dalam proses terapi perilaku dijumpai keterlambatan yang menyolok, maka perlu diwaspadai kemungkinan penyebab gejala yang lebih komplek.

\footnotetext{
${ }^{6}$ Lorna Wing, Autistik Children a Guide for Parents and Professionals (New Jersey: The Chitadel Press, 1974), 67.

${ }^{7}$ Richard P. Halgin, Autism from Theoritical Underestanding to Educational Interventation (London: Whure Publisher Ltd, 1998), 235.

${ }^{8}$ Handojo, Autisma Petunjuk Praktis, 4.
} 


\section{Gejala-Gejala Autis}

Masalah komunikasi yang paling sering ditemui oleh anak autis yaitu anak terlambat bicara. Sementara kekerapan pada masalah interaksi sosial adalah tidak adanya kontak mata. Untuk minat yang terbatas, masalah yang sering ditemukan adalah stimulasi diri seperti jalan jinjit, berputar-putar, membentur-benturkan tubuh atau kepala berulang kali serta masalah sensitifitas pada lima indra.

Menurut Y. Handojo, anak autisme memiliki karakteristik atau ciri-ciri khusus antara lain:

a. Selektif berlebihan terhadap rangsang.

b. Kurangnya motivasi untuk menjelajahi lingkungan baru.

c. Respon stimulasi diri sehingga mengganggu integrasi sosial.

d. Respon unik terhadap imbalan (reinforcement), khususnya imbalan dari stimulasi diri. $^{9}$

\section{Diagnosa Anak Autis}

Untuk menegakkan sebuah diagnosa bahwa seorang anak mengidap autis, ada beberapa kriteria yang harus dipenuhi. Selama ini panduan yang dipakai dokter, psikiater, atau psikolog biasanya merujuk pada ICD-10 (International Clasification of Disease) 1993, atau menggunakan rumusan dalam DSM-IV (Diagnostic Statistical Manual)1994 yang disusun oleh kelompok Psikiatri di Amerika Serikat sebagai panduan untuk menegakkan diagnosa. Pada dasarnya diagnosa autisme yang ditegakkan berdasarkan ICD-10 dan DSM-IV menunjukkan kriteria yang sama. Orang tua sebenarnya dapat mencoba mengecek sendiri apakah anaknya termasuk kategori autisme atau tidak dengan memperhatikan kriteria autisme yang ada di dalam DSMIV, berikut panduannya : ${ }^{10}$

a. Harus ada sedikitnya 6 gejala dari (1), (2), dan (3) dengan minimal 2 gejala dari (1) dan masing-masing1 gejala dari (2) dan (3).

1) Gangguan kualitatif dalam interaksi sosial yang timbal balik. Minimal 2 gejala dari gejala-gejala di bawah ini :

a) Tak mampu menjalin interaksi sosial yang cukup memadai: kontak mata sangat kurang, ekspresi mata yang kurang hidup, gerak-gerik yang kurang tertuju.

b) Tidak bisa bermain dengan teman sebayanya.

c) Tak dapat merasakan apa yang dirasakan orang lain.

d) Kurangnya hubungan sosial dan emosional yang timbal balik.

2) Gangguan kualitatif dalam bidang komunikasi. Minimal 1 dari gejala-gejala di bawah ini :

a) Bicara terlambat atau bahkan sama sekali tidak berkembang (tidak ada usaha untuk mengimbangi komunikasi dengan cara lain tanpa bicara).

b) Bila bisa bicara, bicaranya tidak dipakai untuk komunikasi.

c) Sering menggunakan bahasa yang aneh dan diulang-ulang.

\footnotetext{
${ }^{9}$ Ibid., 13.

${ }^{10}$ Yurike Fauziah Wardhani, Autisme Terapi Medis Alternatif (Jakarta: Lembaga Penerbit Fakultas Ekonomi Universitas Indonesia, 2009), 13.
} 
d) Cara bermain yang kurang variatif, kurang imajinatif, dan kurang bisa meniru.

3) Suatu pola yang dipertahankan dan diulang-ulang dari perilaku, minat, dan kegiatan sedikitnya harus ada 1 dari gejala-gejala di bawah ini: ${ }^{11}$

a) Mempertahankan satu minat atau lebih, dengan cara yang sangat khas dan berlebih-lebihan.

b) Terpaku pada suatu kegiatan yang ritualistik atau rutinitas yang tidak berguna.

c) Ada gerakan-gerakan yang aneh dan diulang-ulang.

d) Seringkali terpaku pada bagian-bagian benda.

b. Sebelum umur 3 tahun tampak adanya keterlambatan atau gangguan dalam bidang:

1) Interaksi sosial,

2) Bicara dan berbahasa,

3) Cara bermain yang kurang variatif.

c. Bukan disebabkan oleh sindroma Rett atau gangguan Disintegratif Masa Kanak.

Tanda-tanda autisme biasanya muncul pada tahun pertama dan selalu sebelum anak berusia 3 tahun. Autisme 2-4 kali lebih sering ditemukan pada anak laki-laki dibandingkan anak perempuan. ${ }^{12}$

Selain itu dapat juga dipakai checklist deteksi autisme berdasarkan ICD-10 dari WHO berikut. Kelompok satu merupakan gejala interaksi sosial, kelompok dua gejala komunikasi dan kelompok, kelompok tiga gejala prilaku tak wajar. Bila anda menemukan minimal total ada 6 gejala secara keseluruhan, dengan ketentuan masingmasing minimal 2 gejala dikelompok satu, 1 gejala di kelompok dua, dan 1 gejala di kelompok tiga, pada seorang anak, maka diagnosa autisme dapat ditegakkan. ${ }^{13}$

\section{Tabel II}

Deteksi Autisme Berdasarkan

(International Clasification of Disease)

\begin{tabular}{|c|c|c|c|c|c|}
\hline $\begin{array}{c}\mathrm{Ke} \\
1\end{array}$ & $\begin{array}{l}\mathrm{N} \\
\mathrm{O}\end{array}$ & Gejala & $\sqrt{ }$ & Jml & KET \\
\hline 1 & $\mathrm{~A}$ & Interaksi sosial tidak memadahi & & & \\
\hline & & a. Kontak mata sangat kurang & & & \\
\hline & & b. Ekspresi muka kurang hidup & & & \multirow{9}{*}{$\begin{array}{l}\text { Min } 2 \\
\text { Gejala }\end{array}$} \\
\hline & & c. Gerak-gerik yang kurang tertuju & & & \\
\hline & & d. Menolak untuk dipeluk & & & \\
\hline & & e. Tidak menengok bila dipanggil (cuek) & & & \\
\hline & & f. Menangis atau tertawa tanpa sebab & & & \\
\hline & & g. Tidak tertarik pada mainan & & & \\
\hline & & h. Bermain dengan bendayang bukan mainan & & & \\
\hline & $\mathrm{B}$ & Tidak bisa bermain dengan teman sebaya & & & \\
\hline & $\mathrm{C}$ & Tidak dapat merasakan apa yang dirasakan orang lain & & & \\
\hline
\end{tabular}

\footnotetext{
${ }^{11}$ Ibid., 14.

${ }^{12}$ Christopeh Sunu, Unlocking Autism (Yogyakarta : Lintang terbit, 2012), 13-14.

${ }^{13}$ Wardhani, Autisme, 17.
} 


\begin{tabular}{|c|c|c|c|c|}
\hline & $\mathrm{D}$ & $\begin{array}{l}\text { Kurangnya hubungan sosial dan emosional yang timbal } \\
\text { balik }\end{array}$ & & \\
\hline \multirow[t]{4}{*}{2} & $\mathrm{~A}$ & $\begin{array}{l}\text { Bicara terlambat atau bahkan sama sekali tidak } \\
\text { berkembang (dan tak ada usaha mengimbangi } \\
\text { komunikasi dengan cara lain tanpa bicara), menarik } \\
\text { tangan bila ingin sesuatu bahasa isyarat tak berkembang }\end{array}$ & \multirow{4}{*}{.............. } & \multirow[t]{4}{*}{$\begin{array}{l}\text { Min } 1 \\
\text { Gejala }\end{array}$} \\
\hline & $\mathrm{B}$ & $\begin{array}{l}\text { bila bisa bicara, bicaranya tidak dipakai untuk } \\
\text { komunikasi }\end{array}$ & & \\
\hline & $\mathrm{C}$ & $\begin{array}{l}\text { sering menggunakan bahasa yang aneh dan diulang- } \\
\text { ulang }\end{array}$ & & \\
\hline & $\mathrm{D}$ & $\begin{array}{l}\text { Cara bermain kurang variatif,kurang imajinatif, dan } \\
\text { kurang bisa meniru }\end{array}$ & & \\
\hline \multirow[t]{4}{*}{3} & A & $\begin{array}{l}\text { Mempertahankan satu minat atau lebih dengan cara yang } \\
\text { sangan khas dan berlebih-lebih }\end{array}$ & & $\begin{array}{l}\text { Min } 1 \\
\text { Gejala }\end{array}$ \\
\hline & $\mathrm{B}$ & $\begin{array}{l}\text { Terpaku pada satu kegiatan yang ritualistik atau rutinitas } \\
\text { yang tak ada gunanya, misalnya makanan dicium dulu }\end{array}$ & $\cdots$ & \\
\hline & $\mathrm{C}$ & $\begin{array}{l}\text { Ada gerakan-gerakan yang aneh yang khas dan diulang- } \\
\text { ulang }\end{array}$ & & \\
\hline & $\mathrm{D}$ & sering kali sangat terpaku pada bagian-bagian benda & & \\
\hline \multicolumn{3}{|r|}{ JUMLAH } & & 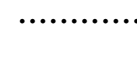 \\
\hline & & $\begin{array}{l}\text { OSA AUTISME DAPAT KONFIRMASIKAN BILA } \\
\text { SEMUANYA MINIMAL } 6\end{array}$ & $H: G$ & \\
\hline
\end{tabular}

Menurut Derek Wood dkk. Gejala-gejala autisme mulai tampak sejak masa yang paling awal dalam kehidupan mereka, gejala-gejala tersebut tampak ketika bayi menolak sentuhan orangtuanya, tidak merespon kehadiran orangtuanya, melakukan kebiasaan-kebiasaan lainnya yang tidak dilakukan oleh bayi-bayi normal pada umumnya. Ketika memasuki umur dimana mereka seharusnya mulai mengucapkan beberapa kata, misalnya ayah, ibu, dan seterusnya. Di samping itu, ia juga mengalami keterlambatan dalam beberapa perkembangan kemampuan yang lainnya. ${ }^{14}$

Dalam buku Bandi Delphie, mengatakan bahwa gejala-gejala anak autis antara lain: ${ }^{15}$

a. Senang tidur bermalas-malasan atau duduk menyendiri dengan tampang acuh, muka pucat, dan mata sayu dan selalu memandang ke bawah.

b. Selalu diam sepanjang waktu.

c. Jika ada pertanyaan terhadapnya, jawabannya sangat pelan dengan nada monoton, kemudian dengan suara yang aneh ia akan mengucapkan atau menceritakan dirinya dengan beberapa kata, kemudian diam menyendiri lagi.

d. Tidak pernah bertanya, tidak menunjukkan rasa takut, tidak punya keinginan bermacam-macam, serta tidak menyenangi sekelilingnya.

\footnotetext{
${ }^{14}$ Derek Wood dkk, Kiat Mengatasi Gangguan Belajar (Yogyakarta: Kata Hati, 2005), 235.

${ }^{15}$ Bandi Delphie, Pembelajaran Anak Berkebutuhan Khusus (Bandung: Refika Aditama, 2006), 121.
} 
e. Tidak tampak ceria.

f. Tidak perduli terhadap lingkungannya, kecuali pada benda yang disukainya, misalnya boneka.

Dari pendapat-pendapat di atas, maka dapat disimpulkan bahwa ciri-ciri khusus dan gejala-gejala yang timbul pada anak autis sangat beragam dan tergantung dari tingkat parah tidaknya seorang anak mengidap autis. Salah satu ciri dan gejala yang timbul pada umumnya yaitu tidak adanya kontak mata, bergerak berulang-ulang, suka dengan dunianya sendiri. Pada intinya anak autis mengalami masalah gangguan pada perkembangan perilaku dan berbicaranya sehingga mereka tidak mampu mengadakan interaksi sosial dan seolah-olah hidup dalam dunianya sendiri.

\section{Perlunya Perhatian Khusus bagi Siswa Autis}

Perlu diingat bahwa pada anak kita yang normal pun, kita tidak mungkin menentukan dengan pasti apakah pendidikan yang kita berikan kepadanya akan berhasil memenuhi harapan kita. Banyak anak normal yang mendapat kesempatan menempuh pendidikan yang normal dan canggih, setelah dewasa dia tidak berhasil memanfaatkannya.

Sangat perlu dipahami oleh para orang tua yang anaknya menyandang autisme bahwa terapi harus dimulai sedini mungkin sebelum usia 5 tahun, karena perkembangan paling pesat dari otak manusia terjadi pada usia sebelum 5 tahun, puncaknya pada usia 2-3 tahun. Oleh sebab itu, penatalaksanaan terapi setelah usia 5 tahun hasilnya berjalan lebih lambat. Pada usia 5-7 tahun perkembangan otak melambat menjadi $25 \%$ dari usia sebelum 5 tahun.

Meskipun anak autisme ini mempunyai kelainan perilaku, kita berikan kesempatan untuk belajar kepada anak autisme ini, sehingga walaupun perkembangan perilakunya tidak secepat anak normal, dia masih dapat menguasai beberapa kemampuan yang mungkin dapat menyebabkan timbulnya kemandirian pada dirinya setelah dia dewasa kelak.

Adapun perhatian-perhatian khusus atau jenis-jenis terapi yang bisa diberikan pada anak autis ini sebagai berikut: ${ }^{16}$

a. Terapi perilaku.

Berbagai jenis terapi telah dikembangkan untuk mendidik anak-anak dengan kebutuhan khusus, termasuk penyandang autisme mengurangi perilaku yang tidak lazim dan menggantinya dengan perilaku yang bisa diterima dalam masyarakat. Terapi perilaku sangat untuk membantu para anak-anak ini untuk lebih bisa menyesuaikan diri dalam masyarakat. Bukan saja pendidiknya yang harus menerapkan terapi perilaku pada saat belajar mengajar, namun setiap anggota keluarga di rumah harus bersikap sama dan konsisten dalam menghadapi anakanak dengan kebutuhan khusus ini. Terapi perilaku terdiri dari terapi okupasi, terapi wicara, dan menghilangkan perilaku yang asosial.

b. Terapi okupasi.

\footnotetext{
${ }^{16}$ Handojo, Autisma Petunjuk Praktis, 29.
} 
Sebagian penyandang kelainan perilaku, terutama anak autisme, juga mempunyai perkembangan motorik yang kurang baik. Gerakgeriknya kasar dan kurang luwes bila dibandingdengan anak-anak seumurnya. Pada anak-anak ini perlu diberi bantuan terapi okupasi untuk membantu menguatkan, memperbaiki koordinasi dan keterampilan ototnya. Otot jari tangan misalnya sangat penting dikuatkan dan dilatih supaya anak bisa menulis dan melakukan semua hal yang membutuhkan keterampilan otot jari tangannya, seperti menunjuk, bersalaman, memegang pensil, memetik gitar dan sebagainya.

Para terapis okupasi jika sering memakai sensory integeration (SI) untuk menterapi kelainan sensoris pada anak autisme. Namun dari banyak penelitian yang dilakukan, dibuktikan bahwa SI saja tidak dapat meningkatkan perilaku anak, bahkan sering mengakibatkan kemunduran perilaku, dan tidak berhasil menghilangkan ataupun mengurangi perilaku-perilaku aneh dari anak. ${ }^{17}$

c. Terapi wicara.

Bagi anak dengan Speech delay atau keterlambatan bicara, maka terapi wicara merupakan pilihan utama. Untuk memporoleh hasil yang optimal, materi speech therapy sebaiknya dilaksanakan dengan metode ABA (Applied Behaviour Analysis) atau metode Lovaas. Bagi semua penyandang autisme yang mempunyai keterlambatan bicara dan kesulitan berbahasa, speech therapy adalah suatu keharusan, tetapi pelaksanaannya harus dengan metode ABA tersebut. Penerapan terapi wicara pada anak penyandang autisme berbeda dengan anak lain. Terapis harus berbekal diri dengan pengetahuan yang cukup mendalam tentang gejala dan gangguan bicara yang khas bagi penyandang autisme.

d. Sosialisasi dengan menghilangkan perilaku yang tidak wajar.

Untuk menghilangkan perilaku yang tidak dapat diterima oleh masyarakat umum, perlu dimulai dari kepatuhan dan kontak mata, kemudian diberikan pengenalan konsep atau kognitif melalui bahasa reseptif dan ekspresif. Setelah itu barulah anak dapat diajarkan hal-hal yang bersangkutan dengan tata krama. Agar seluruh perilaku asosial itu dapat ditekan, maka penting sekali diperhatikan bahwa anak jangan dibiarkan sendirian tetapi harus selalu ditemani secara interaktif. Seluruh waktu pada saat anak bangun, perlu diisi dengan kegiatan interaktif, baik yang bersangkutan dengan akademik, bina diri, keterampilan motorik, sosialisasi, dan jangan lupa, disediakan dan diberikan imbalan yang efektif. ${ }^{18}$

e. Terapi biomedik (obat, vitamin, mineral, food suplement).

Obat-obatan juga dipakai terutama untuk anak penyandang autisme. tetapi sifatnya sangat individual dan perlu berhati-hati. Dosis dan jenisnya sebaiknya diserahkan kepada dokter spesialis yang memahami dan mempelajari autisme. Baik obat maupun vitamin hendaknya diberikan secara berhati-hati, karena baik obat maupun vitamin dapat memberikan efek yang tidak dikehendaki. Jenis obat, food supplement dan vitamin yang sering dipakai saat ini untuk anak autisme

\footnotetext{
17 Ibid.

18 Ibid., 30.
} 
adalah risperidone (risperdal), ritalin, haloperidol, pyridoksin (vit B6), DMG (vit B15), TMG, magnesium, omega-3, dan omega-6. Sebaiknya tiap obat dan vitamin diberikan kepada penyandang autisme dengan tujuan efek yang sudah diketahui. Efek serta efek sampingnya perlu secara cermat diamati, sehingga diperoleh manfaat yang optimal. ${ }^{19}$

f. Sosialisasi ke sekolah reguler.

Anak dengan kelainan perilaku, terutama penyandang autisme yang telah mampu bersosialisasi dan berkomunikasi dengan baik, dapat dicoba untuk memasuki sekolah 'normal' sesuai dengan umurnya. Namun perlu diingat bahwa terapi perilakunya jangan ditinggalkan, karena sangat besar kemungkinan terjadi regresi yaitu perkembangan perilaku anak yang mundur kembali. Sebaiknya keikutsertaan di sekolah normal tetap diimbangi dengan penanganan perilaku yang tetap terus dikembangkan dan dipelihara. Perlu diingat pula bahwa bagi anak dengan autisme yang masuk sekolah normal harus dipantau terus (oleh shadower dan helper). Di lingkungan sekolah normal, anak-anak ini dapat dilatih untuk kemampuan komunikasi dan sosialisasi dengan anak-anak sebayanya. Sedangkan materi akademiknya bila terjadi kesulitan, tetap dapat diajarkan secara One on One.

g. Sekolah Anak Berkebutuhan Khusus.

Di dalam pendidikan khusus ini, biasanya telah diterapkan terapi perilaku, terapi wicara dan terapi okupasi. Dan bila perlu dapat ditambah dengan terapi obat-obatan, vitamin dan nutrisi yang memadai. Pendidikan anak dengan kebutuhan khusus ini tidak dapat disamakan dengan pendidikan normal, karena kelainannya sangat bervariatif dan usia mereka juga berbeda-beda. Cara penatalaksanaannya sangat jauh berbeda dengan pendidikan normal. Kalau di pendidikan normal seorang pendidik dapat menangani beberapa anak sekaligus, maka untuk anak dengan kebutuhan khusus ini, biasanya seorang terapis hanya mampu menangani seorang anak pada saat yang sama (One on One).

Dengan deteksi dini ini, diharapkan para orang tua anak autis dapat segera mengambil keputusan dan langkah-langkah penaggulangan yang tepat. Diharapkan pula para pendidik profesional yang mengatasi anak autisme ini dapat menyediakan fasilitas layanan terpadu sehingga memudahkan anak autisme dalam proses belajar mengajar dan orang tua sebagai pendorong bagi anaknya untuk bisa normal kembali. ${ }^{20}$

Dapat kita pahami bahwa jenis-jenis terapi yang bisa diberikan pada anak autis yaitu Terapi perilaku, Terapi okupasi, Terapi wicara, Sosialisasi dengan tujuan untuk menghilangkan perilaku yang tidak wajar, Terapi biomedik (obat, vitamin, mineral, food suplement), Sosialisasi ke sekolah reguler dan Belajar di Sekolah Anak Berkebutuhan Khusus.

\section{B. Tinjauan tentang Problematika Pembelajaran Anak Autis}

\footnotetext{
${ }^{19}$ Ibid., 31.

${ }^{20}$ Handojo, Autisma Petunjuk Praktis, 33.
} 


\section{Problematika Pembelajaran}

Dalam proses belajar atau dalam melaksanakan pendidikan perlu diperhatikan adanya beberapa faktor yang dapat mempengaruhi proses pembelajaran, dan faktorfaktor tersebut ikut menentukan berhasil dan tidaknya pembelajaran. problematika yang timbul dalam pembelajaran pendidikan agama Islam bila dilihat dari faktorfaktor pembelajarannya antara lain:

a. Tujuan

Pendidikan agama Islam diajarkan bertujuan untuk meningkatkan keimanan, pemahaman, penghayatan, dan pengalaman peserta didik tentang agama Islam, sehingga menjadi manusia muslim yang beriman dan bertakwa kepada Allah SWT serta berakhlak mulia dalam kehidupan pribadi, bermasyarakat, berbangsa dan bernegara.

Dari tujuan tersebut dapat ditarik beberapa dimensi yang hendak ditingkatkan dan dituju oleh kegiatan pembelajaran pendidikan agama Islam, yaitu :

1) Dimensi keimanan peserta didik terhadap ajaran agama Islam.

2) Dimensi pemahaman atau penalaran (intelektual) serta keilmuan peserta didik terhadap ajaran agama Islam.

3) Dimensi penghayatan atau pengalaman batin yang dirasakan peserta didik dalam menjalankan ajaran agama Islam

4) Dimensi pengamalannya, dalam arti bagaimana ajaran Islam yang telah diimani, dipahami, dan dihayati atau diinternalisasi oleh peserta didik itu mampu menumbuhkan motivasi dalam dirinya untuk menggerakkan, mengamalkan, dan menaati ajaran agama dan nilai-nilainya dalam kehidupan pribadinya serta merealisasikan dalam kehidupan bermasyarakat, berbangsa, bernegara dan sehari-hari. ${ }^{21}$

Tujuan pembelajaran adalah pernyataan tentang hasil pembelajaran apa yang diharapkan. Adapun yang menjadi problem tujuan adalah $:^{22}$

1) Tujuan pembelajaran tidak dirumuskan dengan jelas, baik tujuan yang bersifat umum maupun khusus, hasil pencapaian pembelajaran bagaimanakah yang diharapkan, sehingga dapat timbul pertanyaan dalam diri siswa untuk apakah saya belajar pendidikan agama Islam dan apa gunanya.

2) Tujuan pembelajaran yang terlalu tinggi sehingga tujuan tidak akan pernah tercapai karena tujuan tersebut tidak sesuai dengan kemampuan siswa maupun guru dan keadaan pembelajaran yang ada.

b. Materi

Menurut Rusdinah dalam Paradigma Pendidikan Agama Islam mengemukakan beberapa kelemahan dari pendidikan agama Islam, baik dalam pemahaman materi Pendidikan Agama Islam maupun dalam pelaksanaannya, yaitu:

1) Dalam bidang teologi, ada kecenderungan mengarah pada paham fatalistik.

\footnotetext{
${ }^{21}$ Muhaimin, Paradigma pengertian Pendidikan Islam (Bandung: PT.Remaja Rosdakarya, 2004), 78.

${ }^{22}$ Irfan Abdul Gafar dan Muhammad Jamil, Re-Formulasi Rancangan Pembelajaran Pendidikan Agama Islam (Jakarta: PT. Remaja Rosdakarya, 2003), 32.
} 
2) Bidang akhlak yang berorientasi pada urusan sopan santun dan belum dipahami sebagai keseluruhan pribadi manusia beragama.

3) Bidang ibadah diajarkan sebagai kegiatan rutin agama dan kurang ditekankan sebagai proses pembentukan kepribadian.

4) Dalam bidang hukum (fiqih) cenderung dipelajari sebagai tata aturan yang tidak akan berubah sepanjang masa, dan kurang memahami dinamika dan jiwa hukum Islam.

5) Agama Islam cenderung diajarkan sebagai dogma kemajuan ilmu pengetahuan.

6) Orientasi mempelajari Al-Qur'an masih cenderung pada kemampuan membaca teks, belum mengarah pada pemahaman arti dan penggalan makna. ${ }^{23}$

c. Guru

Dalam Peraturan Pemerintah tentang Standar Nasional Pendidikan sebagaimana dikutip di atas, ditegaskan agar proses pembelajaran diselenggarakan dengan menyenangkan, motivatif, inspiratif agar terjadi proses pengambangan kreatifitas. Dengan demikian model-model sekolah feodal yang memberi ruang pada hukuman fisik kini sudah tidak memperoleh ruang dalam pendidikan dan proses pembelajaran. Guru memperoleh ruang dalam pendidikan dan pembelajaran. Guru dengan demikian harus mendefinisi tentang pengembangan proses pembelajarandari proses mengubah perilaku anak dengan dengan memfasilitasi anak untuk berubah.

Pendidikan sebagai ilmu (paedagogik), sebagaimana ilmu yang lain memiliki objek material dan objek formal. Objek material dari pendidikan, sebagaimana objek material dari ilmu-ilmu sosial dan humaniora yang lain adalah manusia. Sedangkan objek formal dari pendidikan adalah problem-problem yang menyangkut apa, siapa, mengapa, dan bagaimana dalam hubungannya dengan usaha membawa anak didik pada suatu tujuan tertentu. Dengan kata lain, objek formal dari pendidikan adalah kegiatan manusia dalam upayanya membawa/membimbing manusia lain ke arah kedewasaan dalam artian mampu mandiri, yaitu terlepas dari kebergantungan penuh kepada orang lain. ${ }^{24}$

Untuk menjadi guru yang baik itu harus memenuhi tujuh kriteria, antara lain: ${ }^{25}$

1) Sifat; guru yang baik harus memiliki sifat-sifat antusias, stimulatif, mendorong siswa untuk maju, hangat, berorientasi pada tugas dan pekerja keras, toleransi, sopan dan bijaksana, bisa dipercaya, fleksibel, dan mudah menyesuaikan diri, demokratis, penuh harapan bagi siswa, tidak semata mencuri reputasi pribadi, mampu mengatasi strereotype siswa, bertanggungjawab terhadap kegiatan belajar siswa, mampu menyampaikan perasaannya, dan memiliki pendengaran yang baik.

\footnotetext{
${ }^{23}$ Muhaimin, Paradigma, 89.

${ }^{24}$ Abu Ahmadi dan Nur Uhbayati, Ilmu Pendidikan (Jakarta : Rineka Cipta, 1991), 68.

${ }^{25}$ Dede Rosyada, Paradigama Pendidikan Demokratis (Jakarta: Prenada Media, 2004), 15-17.
} 
2) Pengetahuan; Guru yang baik juga memiliki pengetahuan yang memadai dalam mata pelajaran yang diampunya, dan terus mengikuti kemajuan dalam bidang ilmunya itu.

3) Apa yang disampaikan; Guru yang baik juga mampu memberikan jaminan bahwa materi yang diharapkan mencakup semua unit bahasan yang diharapkan siswa secara maksimal.

4) Bagaimana mengajar; Guru yang baik mampu menjelaskan berbagai infomasi secara jelas dan terang, memberikan layanan yang variatif, menciptakan dan memelihara memonetum, menggunakan kelompok kecil secara efektif, memandang semua siswa untuk berpartisipasi, memonitor, dan bahkan sering mendatangi siswa, mampu mengambil keuntungan dari kejadian-kejadian yang tidak diharapkan, memonitor tempat duduk siswa, senantiasa melakuskan formatif test dan post test, melibatkan siswa dalam tutorial atau pengajaran sebaya, menggunakan kelompok besar untuk pengajaran instruktional, menghindari kesukaran yang kompleks dengan menyederhanakan saja informasi, menggunakan beberapa bahan tradisional, menunjukkan pada siswa tentang pentingnya bahan-bahan yang mereka punyai, menunjukkan proses berfikir yang penting untuk belajar, berpartisipasi dan mampu memberikan perbaikan terhadap kesalahan konsepsi yang dilakukan siswa.

5) Harapan; Guru yang baik mampu memberikan harapan pada siswa, mampu membuat siswa akuntabe, dan mendorong partisipasi orang tua dalam memajukan kemampuan akademik siswanya.

6) Reaksi guru terhadap siswa; Guru yang baik biasa menerima berbagai masukan, resiko, dan tantangan konsistensi dalam kesepakatankesepakatan dengan siswa, bijaksana terhadap kritik siswa, menyesuaikan diri dengan kemajuan-kemajuan siswa, pengajaran yang memperhatikan individu, mampu memberikan jaminan atas kesetaraan partisipasi siswa, mempu menyediakan waktu yang pantas untuk siswa bertanya, cepat dalam memberikan pengarahan/pengajaran bagi siswa dalam membantu mereka belajar, peduli dan sensitif terhadap perbedaan-perbedaan latar belakang sosial ekonomi dan kultur siswa, dan menyesuaikannya pada kebijakan menghadapi berbagai perbedaan.

7) Managemen; Guru yang baik juga harus mampu menunjukkan keahlian dalam perencanaan, memiliki kemampuan mengorganisasi kelas sejak hari pertama dia bertugas, mampu merancang kelas multi dimensional sebagaimana dia juga mampu menyusun bangku belajar siswa secara dinamis dan sesuai dengan suasana belajar yang akan dikembangkannya, cepat memulai kelas, melewati masa transisi dengan baik, memiliki kemampuan dalam mengatasi dan/atau pembelajaran kelas dalam satu waktu yang sama, mampu memelihara waktu bekerja serta menggunakannya secara efisien dan konsisten, dapat meminimalisasi gangguan, dapat menerima suasana kelas yang ribut dengan kegiatan pembelajaran, memiliki teknik untuk mengontrol kelas, memberi hukuman dengan bentuk yang paling ringan, dapat memelihara suasana tenang 
dalam belajar, dan tetap dapat menjaga siswa untuk tetap belajar menuju sukses.

d. Peserta Didik

Peserta didik adalah makhluk yang tumbuh dan berkembang. Mereka merupakan individu dinamis yang memiliki karakteristik tertentu pada setiap perkembangannya. Pertumbuhan dan perkembangann ini merupakan proses alami yang terjadi dalam kehidupan manusia. ${ }^{26}$

Perkembangan peserta didik memiliki konsekuensi kepada perlakuan pendidikan. Pada masa bayi pendidikan yang dilaksanakan oleh orang dewasa lebih banyak memberikan bantuan pada perkembangan fisik, seperti bantuan orang tua kepada anak agar dapat menfungsikan kakinya untuk berjalan. Hal ini terus dilakukan sampai anak memiliki kemampuan mengendalikan dan menfungsikan organ tubuhnya. Menginjak usia sekolah taman kanak-kanak proses pendidikan bukan hanya sekadar melatih organ tubuhnya agar berfungsi lebih sempurna, akan tetapi juga mengembangkan kemampuan psikologis yang mulai berkembang, misalnya memgembagkan keberanian melalui permainan-permainan ${ }^{27}$.

Mempelajari perkembangan peserta didik merupakan suatu keharusan bagi setiap pendidik. Ada beberapa alasan mengapa pendidik perlu memahami faktor problem perkembangan peserta didik, yaitu: ${ }^{28}$

1) Kemampuan atau kecerdasan siswa yang kurang, cara mengatasi problem ini yaitu dengan mempelajari dan memahami karakteristik perkembangan peserta didik.

2) Motivasi mempelajari pendidikan agama Islam yang rendah dan tidak ada kesungguhan dalam mempelajari pendidikan agama Islam, cara mengatasi problem ini yaitu dengan melalui pemahaman tentang faktor-faktor yang mempengaruhi perkembangan peserta didik baik di lingkungan keluarga, sekolah maupun masyarakat. Disamping itu, dapat diantisipasi juga tentang upaya untuk mencegah berbagai kendala atau penghambat yang mungkin akan mengontaminasi perkembangan mereka.

3) Siswa tidak suka terhadap pelajaran pendidikan agama Islam atau guru mata pelajaran tersebut, cara mengatasi problem ini yaitu dengan menanamkan presepsi kepada guru bahwa Peserta didik memiliki potensi yang multidimensi yang meliputi biopsikososiospiritual (fisik/biologis, psikologis, sosial, dan moral-spiritual). Pemahaman terhadap keragaman dimensi potensi ini memberikan implikasi terhadap kebijakan pendidikan, baik menyangkut penentuan arah atau tujuan, kompetensi guru, model kurikulum, maupun penyiapan fasilitas (sarana dan prasarana pendidikan).

e. Media

Secara bahasa kata media berasal dari bahasa Latin medius yang berarti tengah, perantara atau pengantar. ${ }^{29}$ Selaras dengan pendapat Heinich, Molenda dan Russel

\footnotetext{
${ }^{26}$ Desmita, Psikologi Perkembangan Peserta Didik (Bandung: Remaja Rosdakarya, 2012), 39.

${ }^{27}$ Wina Sanjaya, Perencanaan dan Desain Sistem Pembelajaran (Jakarta: Kencana, 2008), 255-256.

${ }^{28}$ Syamsu Yusuf dan Nani M. Sugandhi, Perkembangan Peserta Didik (Jakarta: Raja Grafindo Persada, 2012), 5-6.
} 
yang dikutip oleh Wina Sanjaya, mengungkapkan bahwa media is a channel of communication. Derived from the Latin word for "between", the term refers to "anything that carries information between a source and a receiver. Media adalah sebuah alat komunikasi. Berasal dari bahasa Latin yang berarti "antara", maksud term tersebut adalah apapun yang menyampaikan informasi antara sumber dan penerimanya. ${ }^{30}$

Zakiah Daradjat dkk memberikan definisi bahwa media pendidikan adalah suatu benda yang dapat diindra, khususnya penglihatan dan pendengaran, baik yang terdapat di dalam maupun di luar kelas, yang digunakan sebagai alat bantu penghubung dalam proses interaksi belajar-mengajar untuk meningkatkan efektifitas hasil belajar peserta didik. ${ }^{31}$

Secara umum, manfaat media dalam proses belajar mengajar adalah memperlancar interaksi antara guru dengan siswa sehingga pembelajaran akan lebih efektif dan efisien. Tetapi secara lebih khusus ada beberapa manfaat media yang lebih rinci, Selain itu media dalam proses belajar mengajar mempunyai kegunaan sebagai berikut:

1) Media dapat megatasi berbagai keterbatasan pengalaman yang dimiliki peserta didik. Pengalaman masing-masing individu beragam karena dipengaruhi lingkungan tempatnya berada. Dalam hal ini media dapat mengatasi perbedaan-perbedaan tersebut.

2) Media dapat mengatasi ruang kelas. Banyak hal yang sukar dialami oleh peserta didik di dalam kelas, seperti objek yang terlalu besar atau terlalu kecil, gerakan-gerakan yang diamati terlalu cepat atau terlalu lambat. Melalui media kesukaran-kesukaran tersebut dapat diatasi.

3) Media memungkinkan adanya interaksi langsung antara peserta didik dengan lingkungan.

4) Media menghasilkan keseragaman pengamatan. Pengamatan peserta didik dapat secara bersama-sama diarahkan kepada hal-hal yang dianggap penting sesuai dengan tujuan yang ingin dicapai.

5) Media dapat menanamkan konsep dasar yang benar, konkrit dan realistis. Penggunaan media seperti gambar, film, grafik dan lainnya dapat memberikan konsep yang benar.

6) Media dapat membangkitkan keinginan dan minat yang baru. Melalui media, pengalaman peserta didik semakin luas, persepsi semakin tajam, dan konsepkonsep dengan sendirinya makin lengkap, sehingga keinginan dan minat baru untuk belajar akan timbul.

7) Media dapat membangkitkan motivasi dan merangsang peserta didik untuk belajar.

8) Media dapat memberikan pengalaman yang integral dari suatu yang konkrit sampai pada yang abstrak. ${ }^{32}$

\footnotetext{
${ }^{29}$ Azhar Arsyad. Media Pembelajaran (Jakarta: PT.Rajagrafindo Persada, 2007), 3.

${ }^{30}$ Wina Sanjaya, Perencanaan dan Desain Sistem Pembelajaran (Jakarta:Kencana, 2009), 204.

${ }^{31}$ Zakiah Daradjat,dkk. Metodik Khusus Pengajaran Agama Islam (Jakarta: Bumi Aksara, 2008), 226.

${ }^{32}$ Asnawir, Basyirudin Usman, Media Pembelajaran (Jakarta: Ciputat Pers, 2002), 14-15.
} 
Media adalah faktor yang sangat penting bagi tercapainya tujuan pembelajaran, akan tetapi yang menjadi problem adalah media yang tersedia dan yang sering digunakan hanyalah media tradisional, misalnya buku-buku dan alat tulis. Sedangkan laboratorium / perpustakaan, audio visual, LCD proyektor dan alat peraga belum dapat terpenuhi secara maksimal.

f. Strategi

Abdul Majid menjelaskan bahwa strategi adalah suatu ilmu atau seni perintah militer yang diterapkan dalam suatu rencana pertempuran besar atau kemampuan menggunakan strategi untuk mengejutkan musuh. Semakin luasnya pengertian strategi Abdul Majid mengutip pendapat dari Mintzberg dan Waters yang menjelaskan strategi adalah pola umum tentang keputusan atau tindakan atau strategi dapat dipahami sebagai rencana atau kehendak yang mendahului dan mengendalikan kegiatan. ${ }^{33}$

Strategi juga bisa diartikan sebagai suatu pola yang direncanakan dan ditetapkan secara sengaja untuk melakukan kegiatan atau tidak. Strategi mencakup tujuan kegiatan, siapa yang terlibat dalam kegiatan, isi kegiatan, proses kegiatan dan sarana penunjang kegiatan. ${ }^{34}$

Dick dan Carey dalam Sanjaya menjelaskan bahwa strategi pembelajaran terdiri atas seluruh komponen materi pembelajaran dan prosedur atau tahapan kegiatan belajar yang digunakan oleh guru dalam rangka membantu peserta didik mencapai tujuan pembelajaran tertentu. Menurut mereka strategi pembelajaran bukan hanya terbatas pada prosedur atau tahapan kegiatan belajar saja, melainkan termasuk juga pengaturan materi atau paket program pembelajaran yang akan disampaikan kepada peserta didik. ${ }^{35}$

Dalam proses belajar mengajar guru mampu menggunakan strategi aktif, sehingga siswa dapat belajar dengan penuh semangat dan antusias untuk mengikuti pembelajaran di kelas. Penggunaan strategi aktif dalam proses pembelajaran merupakan suatu keharusan dalam kegiatan belajar mengajar. Oleh karena itu strategi merupakan komponen yang menentukan terhadap keberhasilan kegiatan belajar mengajar di samping tujuan, materi, dan evaluasi. Strategi yang digunakan adalah betul-betul dapat melayani kebutuhan peserta didik, baik secara individu maupun kelompok merupakan suatu hal yang diharapkan saat ini. Penggunaan strategi yang tepat dapat berpengaruh terhadap efektifitas kegiatan belajar mengajar

g. Evaluasi

Evaluasi dapat diartikan sebagai upaya sistematik untuk menghimpun, menyusun, dan memperoleh data serta informasi yang dapat diolah dan dianalisa menjadi kesimpulan yang berguna bagi landasan pengelolaan program. Evaluasi dilaksanakan untuk mengetahui tingkat keberhasilan pelaksanaan kegiatan pengajaran dalam pencapaian tujuan yang telah ditetapkan. Evaluasi juga

\footnotetext{
${ }^{33}$ Abdul Majid, Strategi Pembelajaran (Bandung: PT Remaja Rosda Karya, 2013), 3.

${ }^{34}$ Ibid., 4.

${ }^{35}$ Wina Sanjaya, Strategi Pembelajaran Berorientasi Standar Proses Pendidikan (Jakarta: Kencana Prenada Media, 2008), 17.
} 
dimaksudkan untuk mengetahui hambatan- hambatan dan kelemahan yang dihadapi dalam pelaksanaan kegiatan pengajaran. Evaluasi belajar yang baik berdasarakan acuan patokan untuk mengetahui apakah tujuan pembelajaran dari kurikulum sudah tercapai. Bila kurikulum sudah tertata rapi dan jelas, akan dapat teridentifikasi dan dapat terukur target pencapaian pembelajaran dan dapat terukur target pencapaian pembelajaran, sehingga evaluasi belajar yang diadakan mampu mempetakan kemampuan siswa. ${ }^{36}$

Data evaluasi belajar diperoleh melalui evaluasi formatif dan evaluasi sumatif. Evaluasi formatif lebih diarahkan kepada pertanyaan sampai dimanakah guru telah berhasil menyampaikan bahan pelajaran kepada siswanya. Evaluasi formatif pada umumnya dilakukan pada akhir satuan pelajaran maupun dalam bentuk ulangan harian. Sedangkan evaluasi sumatif langsung diarahkan kepada keberhasilan siswa mempelajari suatu program pengajaran. Biasanya dilakukan pada akhir program pengajaran yang relatif besar, misalnya: triwulan, tengah semester atau akhir semester. ${ }^{37}$

Lembaga pendidikan adalah sebuah wadah yang digunakan untuk proses pembelajaran, adapun menurut Islam, tujuan pendidikan ialah membentuk manusia supaya sehat, cerdas, patuh dan tunduk kepada perintah Tuhan serta menjauhi larangan-larangan-Nya. Namun dalam menyukseskan tujuan pendidikan tersebut tidaklah mudah. Pasti ada kendala di dalamnya. Menurut Ahmadi dan Uhbiyati, problematika atau kendala dalam proses pembelajaran pendidikan itu menyangkut 5 W dan $1 \mathrm{H}$, yaitu: ${ }^{38}$

a. Problematika Who (Siapa)

Problematika Who (Siapa) yaitu menguraikan kendala dari pendidik dan anak didik sebagai subjek pendidikan.

1) Problem Pendidik

Masalah yang berkaitan dengan pendidik antara lain: Problem kemampuan ekonomi, Problem kemampuan pengetahuan dan pengalaman, Problem kemampuan, Problem kewibawaan, Problem kepribadian, Problem attitude (sikap), Problem sifat, Problem kebijaksanaan, Problem kerajinan, Problem tanggung jawab, Problem kesehatan dan sebagainya.

Masalah yang berkaitan dengan pendidik antara lain rendahnya kualitas guru dan rendahnya kesejahteraan guru. Kedua masalah ini saling berkaitan. Kualitas guru yang rendah dipengaruhi oleh kesejahteraan guru yang rendah, begitu juga sebaliknya. Rendahnya penghasilan yang diterima para guru memaksa mereka untuk mencari pekerjaan sampingan. Hal ini tentunya membuat kualitas para guru menurun karena perhatian mereka tidak hanya tertuju pada tugas mereka sebagai guru

2) Problem Anak Didik

Problem yang berkaitan dengan anak didik juga tidak kalah pentingnya untuk diperhatikan, dipikirkan dan dipecahkan, karena anak didik adalah

\footnotetext{
${ }^{36}$ Zaenal Arifin, Evaluasi Pembelajaran (Bandung: PT Remaja Rosda Karya, 2010), 76.

${ }^{37}$ Ainurrahman, Belajar dan Pembelajaran (Bandung: Alfabet, 2010), 54.

${ }^{38}$ Ahmadi dan Nur Uhbayati, Ilmu Pendidikan, 255.
} 
pihak yang digarap untuk dijadikan manusia yang beriman dan bertakwa kepada Tuhan Yang Maha Esa, berakhlak mulia, sehat, berilmu, cakap, kreatif, mandiri, dan baik dalam keluarga, sekolah maupun masyarakat. Adapun problem-problem yang ada pada anak didik antara lain: a) Problem kemampuan ekonomi keluarga, b) Problem intelegensi, c) Problem bakat dan minat, d) Problem pertumbuhan dan perkembangan, e) Problem kepribadian, f) Problem sikap, g) Problem sifat, h) Problem kerajinan dan ketekunan, i) Problem pergaulan, j) Problem kesehatan.

Selain masalah di atas, ada lagi satu masalah yang sering di alami oleh para siswa yaitu rendahnya prestasi yang dimiliki oleh para siswa. Berdasarkan teori di atas, faktor penyebab masalah yang dihadapi oleh peserta didik dapat digolongkan menjadi dua macam yaitu faktor yang berasal dari dalam diri peserta didik itu sendiri dan faktor yang berasal dari luar diri peserta didik, seperti faktor lingkungan dan faktor keluarga ${ }^{39}$.

b. Problem Why (Mengapa)

Dalam proses pendidikan, tidak semua pelaksanaannya bisa berjalan dengan lancar, tetapi dijumpai rintangan-rintangan atau hambatan-hambatan. Kesulitankesulitan tersebut bisa terdapat pada semua faktor pendidikan yang menghambat jalannya proses pendidikan. Hambatan-hambatan yang dapat dijumpai dalam proses pendidikan antara lain:

1) Mengapa anak-anak sulit bekerja sama sesama mereka.

2) Mengapa masyarakat tidak menghargai jasa guru yang mendidik putra-putri mereka.

3) Mengapa masyarakat sulit dimintai sumbangan tenaga, pikiran dan dana dalam pembangunan prasarana, pendidikan untuk kepentingan anak-anak mereka

4) Mengapa orang tua anak-anak menghalangi kegiatan ekstra kurikuler putraputranya.

5) Mengapa pejabat setempat mengizinkan mendirikan pabrik disebelah sekolah yang mengganggu jalanya proses belajar mengajar.

6) Mengapa penyaluran buku-buku paket tidak sampai atau selalu terlambat datang di sekolah.

7) Mengapa kasus amoral terjadi di kalangan guru, murid, dan orang tua anak. ${ }^{40}$ salah satu hal yang sering menjadi hambatan dalam pendidikan adalah rendahnya kualitas sarana fisik. Untuk sarana fisik misalnya, banyak sekali sekolah dan perguruan tinggi kita yang gedungnya rusak, kepemilikan dan penggunaan media belajar rendah, buku perpustakaan tidak lengkap. Sementara laboratorium tidak standar, pemakaian teknologi informasi tidak memadai dan sebagainya. Bahkan masih banyak sekolah yang tidak memiliki gedung sendiri, tidak memiliki perpustakaan, tidak memiliki laboratorium dan sebagainya.

c. Problem Where (Dimana)

\footnotetext{
${ }^{39}$ Ibid., 256.

${ }^{40}$ Ibid., 258.
} 
Pada umumnya pendidikan itu biasanya dapat dilaksanakan pada yaitu keluarga, sekolah, dan masyarakat. Sistem pendidikan pada masing-masing tempat tersebut tidak sama dan metodenya pun juga berbeda. Pendidikan di sekolahsekolah merupakan pendidikan formal yang diselenggarakan pada umumnya. Jalur pendidikan ini mempunyai jenjang pendidikan yang jelas, mulai dari pendidikan dasar, pendidikan menengah, sampai pendidikan tinggi.

Problem pendidikan keluarga sebagai tempat pendidikan anakanak antara lain adalah situasi keluarga itu sendiri dan letak keluarga yang berbeda di tengahtengah lingkungan yang tidak menguntungkan. Demikian pula sekolah sebagai tempat pendidikan murid-murid, bila letak sekolah itu di tengah-tengah lingkungan yang tidak menguntungkan, juga akan menjadi problema.

Apabila tempat pendidikan itu di masyarakat, yang menjadi problem tempat di masyarakat adalah jika kebudayaan dan peradaban masyarakat itu bertentangan dan norma-norma agama atau normanorma pancasila. ${ }^{41}$

d. Problem When (Kapan)

Problema when (bilamana/kapan) banyak menyangkut tentang penyiapan sesuatu kepada anak didik, sehingga akan timbul beberapa pertanyaan yaitu: 1) Kapan sesuatu materi itu disampaikan 2) Kapan sesuatu hukuman itu dijatuhkan 3) Kapan sesuatu ganjaran itu diberikan 4) Kapan sesuatu kewajiban itu dibebankan 5) Kapan sesuatu perintah itu dilaksanakan. Masalah when (kapan) tidak hanya berkenaan dengan sesuatu yang diberikan, tetapi juga berkenaan usia anak, seperti: 1) Pada usia berapa anak mulai dididik 2) Pada usia berapa pendidikan berakhir. ${ }^{42}$

Anak dari segi pertumbuhan dan perkembangan mengalami perubahan dengan standar periodesasi usia, baik usia kronologis, psikologis, biologis, kejasmanian, dan pengalaman. Yang menjadi problem adalah berkenaan dengan anak penyandang cacat seperti halnya anak autis.

e. Problem What (Apa)

Problem what (apa) menyangkut dasar, tujuan, bahan atau materi, sarana, prasarana, dan media. Masalah materi erat hubungannya dengan kurikulum, silabi dan SAP. Apakah kurikulum, silabi dan SAP sesuai dengan situasi saat itu dan kondisi anak. Masalah sarana adalah bila tidak lengkap sarana pendidikan hal ini akan mengganggu jalannya pendidikan, seperti kurangnya kursi, meja dan buku.

Perubahan sistem pendidikan secara otomatis juga mempengaruhi perubahan kurikulum, silabi, dan SAP. Apabila kurikulum selalu berubah maka pendidik dan anak didik di sekolah akan terombang-ambing. Adanya ketidakserasian antara hasil pendidikan dan kebutuhan dunia kerja ini disebabkan kurikulum yang materinya kurang fungsional terhadap keterampilan yang dibutuhkan ketika peserta didik memasuki dunia kerja.

f. Problem How (Bagaimana)

Masalah how (bagaimana) berkenaan dengan metode atau cara yang akan digunakan dalam proses pendidikan. Anak didik mempunyai sifat dan bakat yang

\footnotetext{
${ }^{41}$ Ibid., 259.
}

42 Ibid., 260. 
berbeda-beda dan pendidik harus mengakui adanya perbedaan tersebut. Problematika how sangat berkaitan dengan problem pendidik. Di sinilah pendidik diuji kualitasnya dalam mengelola pembelajaran. Akan tetapi, banyak guru yang masih memiliki kualitas pengelolaan pembelajaran yang rendah. Oleh karena itu, diperlukan pelatihanpelatihan yang berkenaan dengan peningkatan kualitas dan kompetensi pendidik agar kegiatan pembelajaran terlaksana dengan baik. ${ }^{43}$

\section{Problematika Anak Autis}

Problem siswa autis yang akan dihadapi pada saat usia sekolah. Beberapa permasalahnnya yaitu ${ }^{44}$

\section{a. Communication Abilities}

Mengajari siswa autis untuk berkomunikasi sangatlah berdampak besar pada dirinya. Siswa autis dimungkinkan ada yang kurang dalam memahami bahasa dan ada yang sangat cepat dalam mengembangkan bahasa yang diajarkan oleh gurunya.

b. Social Skills

Lemahnya kemampuan anak autis dalam berinteraksi sosial mempunyai dampak yang sangat beragam seperti kurangnya kualitas berinteraksi dengan sesama temannya dan kelemahan ini kedepannya akan berdampak pada kemampuannya untuk bisa mencapai dan mendapatkan informasi tambahan dalam kehidupan sosialnya.

c. Behavior Problems

Problem-problem yang dilakukan oleh remaja autis meliputi sifat marah, merusak sesuatu, dan agresif kepada dirinya maupun orang lain. Sifat-sifat di atas ini mempunyai beberapa rintangan yang akan dialami oleh penghuni rumah, sekolah, dan grup belajar.

d. Adaptive Living Skills

Terdapatnya kemampuan penyesuaian diri pada Anak autis untuk menolak atau tidak adanya sifat adaptasi sama sekali pada diri Anak autis. Kurangnya kemajuan dalam beradaptasi ini bisa memperburuk keadaannya. Oleh karena itu, anggota keluarga autis harus membantu dan mendukung guna untuk memaksimalkan dan menyeimbangkan antara sifat bebas dan ketergantungan yang dihadapi oleh remaja autis.

Dalam buku Autistik Children terdapat dua kelompok besar yang menjadi masalah pada anak autis yaitu: ${ }^{45}$

a. Masalah dalam memahami lingkungan (problem in understanding the world)

1) Respon terhadap suara yang tidak biasa (unusually responses to sounds). Anak autis seperti orang tuli karena mereka cenderung mengabaikan suara yang sangat keras dan tidak tergerak sekalipun ada yang menjatuhkan benda di sampingnya.

2) Sulit dalam memahami pembicaraan (dificulties in understanding speech).

\footnotetext{
${ }^{43}$ Ibid., 265.

44 Robin L. Gabriels dan Dina E. Hill, Growing Up with Autis; Working with School-Age Children and Adolescent (New York: The Guliford Press, 2007), 229-233.

${ }^{45}$ Wing, Autistik Children, 37.
} 
3) Kesulitan ketika bercakap-cakap (difiltuties when talking).

4) Lemah dalam pengucapan dan kontrol suara (poor pronunciation and voice control). Beberapa anak autis memiliki kesulitan dalam membedakan suara tertentu yang mereka dengar.

5) Masalah dalam memahami benda yang dilihat (problems in understanding things that are seen).

6) Masalah dalam pemahaman gerak isyarat (problem in understanding gesturs). Anak autis memiliki masalah dalam menggunakan bahasa komunikasi; seperti gerakan isyarat, gerakan tubuh, ekspresi wajah.

7) Indra peraba, perasa dan pembau (the senses of touch, taste and smell). Anakanak autis menjelajahi lingkungannya melalui indera peraba, perasa dan pembau mereka. Beberapa anak autis tidak sensitif terhadap dingin dan sakit.

8) Gerakan tubuh yang tidak biasa (unusually bodily movement). Ada gerakangerakan yang dilakukan anak autis yang tidak biasa dilakukan oleh anak-anak yang normal seperti mengepak-ngepakan tangannya, meloncat-loncat, dan menyeringai.

9) Kekakuan dalam gerakan-gerakan terlatih (clumsiness in skilled movements). Anak autis sangat kurang dalam koordinasi dalam berjalan dan berlari atau sebaliknya.

b. Masalah gangguan perilaku dan emosi (dificult behaviour and emotional problems).

1) Sikap menyendiri dan menarik diri (aloofness and withdrawal). seperti tidak mendengar ketika ada orang yang berbicara padanya, ekspresi mukanya kosong.

2) Menentang perubahan (resistance to change). Beberapa anak autis memiliki rutinitas mereka sendiri, seperti mengetuk-ngetuk kursi sebelum duduk, atau menempatkan objek dalam garis yang panjang.

3) Ketakutan khusus (special fears). Anak-anak autis tidak menyadari bahaya yang sebenarnya.

4) Prilaku yang memalukan secara sosial (socially embarrassing behaviour). Anak-anak autis tidak malu untuk berteriak di tempat umum atau berteriak dengan keras di senjang jalan.

5) Ketidakmampuan untuk bermain (inability to play). 


\section{DAFTAR PUSTAKA}

Abdul Majid, Strategi Pembelajaran (Bandung: PT Remaja Rosda Karya, 2013)

Abu Ahmadi dan Nur Uhbayati, Ilmu Pendidikan (Jakarta : Rineka Cipta, 1991)

Ainurrahman, Belajar dan Pembelajaran (Bandung: Alfabet, 2010)

Asnawir, Basyirudin Usman, Media Pembelajaran (Jakarta: Ciputat Pers, 2002)

Azhar Arsyad. Media Pembelajaran (Jakarta: PT.Rajagrafindo Persada, 2007)

Badrut Tamam, Pelita Jukbil Untuk Anak Autis (Jawa Pos: 28 Pebruari, 2008)

Bandi Delphie, Pembelajaran Anak Berkebutuhan Khusus (Bandung: Refika Aditama, 2006)

Christopeh Sunu, Unlocking Autism (Yogyakarta : Lintang terbit, 2012)

Dede Rosyada, Paradigama Pendidikan Demokratis (Jakarta: Prenada Media, 2004)

Derek Wood dkk, Kiat Mengatasi Gangguan Belajar (Yogyakarta: Kata Hati, 2005)

Desmita, Psikologi Perkembangan Peserta Didik (Bandung: Remaja Rosdakarya, 2012)

Irfan Abdul Gafar dan Muhammad Jamil, Re-Formulasi Rancangan Pembelajaran

Pendidikan Agama Islam (Jakarta: PT. Remaja Rosdakarya, 2003)

J. David Smith, Inklusi Sekolah Ramah Untuk Semua (Bandung: Nuansa, 2006)

Kate Wall, Autism and Early Years Practice (London: Sage Publications LTD, 2010)

Lorna Wing, Autistik Children a Guide for Parents and Professionals (New Jersey: The Chitadel Press, 1974)

Muhaimin, Paradigma pengertian Pendidikan Islam (Bandung: PT.Remaja Rosdakarya, 2004)

Richard P. Halgin, Autism from Theoritical Underestanding to Educational Interventation (London: Whure Publisher Ltd, 1998) 
Robin L. Gabriels dan Dina E. Hill, Growing Up with Autis; Working with School-Age Children and Adolescent (New York: The Guliford Press, 2007)

Sa'ad Riya $>$ d $\}$, Al- T\{ifl al-Tawh \}idy: Asra $>$ r al-T\{ifl al-Dha $>$ tawy $>$ wa kayfa Nataa $<$ 'mal Maa'hu (Mesir: Da>r al-Qahirah lilja>mia>'t, 2008)

Syamsu Yusuf dan Nani M. Sugandhi, Perkembangan Peserta Didik (Jakarta: Raja Grafindo Persada, 2012)

Wina Sanjaya, Perencanaan dan Desain Sistem Pembelajaran (Jakarta: Kencana, 2008)

Wina Sanjaya, Strategi Pembelajaran Berorientasi Standar Proses Pendidikan (Jakarta: Kencana Prenada Media, 2008)

Y. Handojo, Autisma Petunjuk Praktis dan Pedoman Materi Untuk Mengajar Anak Normal Autis dan Perilaku Lain (Jakarta: Buana Ilmu Populer, 2003)

Yurike Fauziah Wardhani, Autisme Terapi Medis Alternatif (Jakarta: Lembaga Penerbit Fakultas Ekonomi Universitas Indonesia, 2009)

Zaenal Arifin, Evaluasi Pembelajaran (Bandung: PT Remaja Rosda Karya, 2010)

Zakiah Daradjat,dkk. Metodik Khusus Pengajaran Agama Islam (Jakarta: Bumi Aksara, 2008) 